\title{
ANALISIS KEUNIKAN SUMBERDAYA DAN STRATEGI KEUNGGULAN BERSAING PRODUK KREATIF BAMBU (Studi pada Saung Angklung Udjo Bandung Jawa Barat)
}

\author{
Encep Sopandi \\ Prodi Administrasi Bisnis, Fakultas Ilmu Sosial dan Ilmu Politik, Universitas Nurtanio \\ Bandung \\ Email: Sopandi07@yahoo.com
}

\begin{abstract}
ABSTRAK
Penelitian ini berusaha menganalisis keunikan sumberdaya dan strategi keunggulan bersaing dengan model market commitment yang akan dilihat dampaknya pada kinerja. Tujuan penelitian untuk mengetahui sejauhmana keunikan sumberdaya yang dimilki dapat memberikan keunggulan dengan pendekatan market commitment model sehingga dapat meningkatkan kinerja, studi kasus pada Saung Angklung Udjo Bandung. Metode yang digunakan deskriftif kualitatif. Pengumpulan data melalui observasi, wawancara dan literature/pendapat pakar. Data diambil dari manajemen untuk variabel kinerja dan strategi keunggulan bersaing, data keunikan sumber daya diambil dari pegawai Saung Angklung Udjo dan keadaan nyata di lapangan. Materi diperdalam dengan data kinerja atau reputasi Saung Angklung Udjo dari pendapat pakar atau testimoni pengunjung yang terekam oleh peneliti. Hasil penelitian menunjukan bahwa Saung Angklung Udjo memiliki keunikan sumberdaya yang memadai dilihat dari aspek aset berwujud, aset tidak berwujud dan kapabilitas organisasi. Keunikan tidak berwujud lebih dominan, karena Angklung Udjo adalah produk seni budaya, khas sunda yang telah diakui UNESCO. Kepemilikan lisensi, haki dan copyright dari Angklung yang terbuat dari produk kreatif bambu adalah unik, terutama dalam hal mudah dimainkan dan dapat mengimbangi alat musik dengan teknologi terkini. Strategi market commitment model sudah dijalankan, walau tidak disadari oleh pihak manajemen Saung Angklung Udjo. Kinerja dalam keadaan cukup baik, dan masih dapat ditingkatkan.

Kata Kunci:

Keunikan sumberdaya,strategi keunggulan bersaing,produk kreatif,kerajinan bambu, Angklung Udjo
\end{abstract}

\begin{abstract}
This research seeks to analyze the unique resources and competitive advantage strategy with market commitment model that will see its impact on performance. The purpose of this study was to determine the extent of the resources owned uniqueness can provide advantages to the approach of market commitment model so that it can improve the performance, a case study at Saung Angklung Udjo Bandung. The method used is descriptive qualitative. The collection of data through observation, interviews and literature / expert opinions. Data taken from the management to the variable performance and strategic competitive advantage. Data taken from the uniqueness of the resources employee at Saung Angklung Udjo and the real situation on the ground. Material deepened with performance data or reputation Saung Angklung Udjo of expert opinion or testimony of visitors recorded by investigators. The results showed that Angklung Udjo has a unique, sufficient resources from the aspects of tangible assets, intangible assets and organizational capabilities. The uniqueness of intangible more dominant, because Angklung Udjo is a product of art and culture, Sundanese which has been recognized by UNESCO. License ownership, copyright of Angklung made of bamboo is unique creative products, especially in terms of easy to play and can keep pace with the latest technology instruments. Market commitment models strategy has already started, although not recognized by the management Saung Angklung Udjo. Performance in circumstances quite well, and can still be improved.
\end{abstract}

Key words:

Uniqueness of resources, competitive advantage strategy, creative products, bamboo crafts, Angklung Udjo 


\section{PENDAHULUAN}

Bidang ekonomi kreatif telah memberikan sumbangsih pada bangsa dan negara, informasi menunjukkan bahwa pada tahun 2002-2008 industri kreatif Indonesia menduduki peringkat 6 dari 10 sub sektor industri, dengan rata-rata kontribusi PDB sebesar 7,8\%. (Studi Industri Kreatif Indonesia, 2009).

Ekonomi kreatif telah menyerap 11,8 juta tenaga kerja atau sebesar $10,72 \%$ dari total tenaga kerja nasional pada 2013, di atas target 8,35\%. Ekonomi kreatif telah menciptakan 5,4 juta usaha atau sekitar 9,68\% dari total jumlah usaha nasional, serta memberikan kontribusi terhadap devisa negara sebesar Rp119 Triliun atau sebesar $5,72 \%$ dari total ekspor nasional.

Data dari Kemenparekraf RI, bahwa ekspor karya kreatif Indonesia tengah tahun 2014 mencapai Rp63,1 Triliun atau tumbuh sebesar 7,27\% dibandingkan periode yang sama 2013. Pertumbuhan tertinggi dicapai oleh subsektor kerajinan dengan laju pertumbuhan ekspor sebesar $11,81 \%$ diikuti mode dengan pertumbuhan $7,12 \%$ dengan rincian periklanan sebesar $6,02 \%$ dan arsitektur 5,59\%. Potensi ekonomi kreatif ke depan sangat besar dan dapat menjadi kekuatan baru sebagai sumber daya yang tidak terhabiskan. Hal ini dikarenakan sumber utama adalah orang kreatif yang dapat berkembang dan menciptakan nilai tambah karena iklim yang kondusif dan akan terus tumbuh memberi kontribusi ekonomi maupun non-ekonomi.

Produk kerajinan masyarakat di Indonesia dilihat dari variasi produk dan jenis bahan yang digunakan terhitung cukup banyak, seperti dilihat dari sisi bahan baku, antara lain bambu, rotan, kayu, dan lainnya. Dari sekian banyak bahan baku yang digunakan perajin, bahan baku bambu memiliki peluang dari segi berlimpahnya bahan, dan pasar yang terbuka. Produk kerajinan berbasis bahan baku bambu dapat diidentifikasi antara 
lain: mebel bambu, rumah bambu, alat musik bambu, anyaman bambu, aneka kerajinan selain anyaman bambu. Beragam aneka kerajinan bambu menarik untuk diteliti karena memiliki keunikan dan peluang pasar yang cukup luas, baik pasar domestik maupun internasional, dan yang lebih menarik bagi penulis untuk penelitian ini adalah kerajinan bambu berupa alat musik, yaitu angklung dari Saung Angklung Udjo.

Bambu di Indonesia berlimpah. Indonesia memiliki 12\% koleksi bambu dunia. Namun kenyataan, pemanfaatan bambu di negara kita kalah dibanding dengan negara-negara lain yang tidak memiliki banyak bambu. Hal ini disinyalir karena keterbatasan pengetahuan SDM dari para perajin bambu dan masih ada anggapan dari sebagian masyarakat bahwa bambu sebagai simbol kemiskinan. Misalnya, kalau rumah menggunakan bilik bambu atau di rumah tangga menggunakan perkakas bambu, itu artinya tergolong miskin. Dampaknya, produk-produk kerajinan bambu pun kurang banyak diperhatikan oleh masyarakat. (Mukoddas, Medan bisnis, 2014). Survei terhadap perajin bambu di Saung Angklung Udjo Padasuka Bandung, sebagai penghasil angklung dan souvenir bambu, menunjukkan bahwa pada umumnya produk dari para perajin masih kurang, terutama dalam hal sentuhan kreatifitas dan inovasi, variasi desain, dan kualitas produk.

Informasi awal dari Saung Angklung Udjo dapat dijadikan gambaran bahwa perkembangan jumlah perajin menunjukkan tren menurun dari tahun ke tahun yang diiringi penurunan jumlah penjulan produk souvenir angklung sebagaimana tergambar pada tabel 1 di bawah ini. 
Tabel 1.

Jumlah pengrajin dan penjualan souvenir angklung

\begin{tabular}{|c|c|c|}
\hline Tahun & "Jumlah Perajin & Souvenir Terjua \\
\hline 2010 & 175 orang & 1440 souvenir \\
\hline 2011 & 129 orang & 1380 souvenir \\
\hline 2012 & 147 orang & 973 souvenir \\
\hline 2013 & 80 orang & 536 souvenir \\
\hline 2014 & 70 orang & 836 souvenir \\
\hline
\end{tabular}

Sumber : Kang Bawi, Corporate Sekretariat Saung Anglung Udjo (2015)

Sehubungan dengan data lapangan di atas, penulis tertarik melakukan penelitian tentang keunikan sumberdaya dan strategi keunggulan bersaing produk kreatif kerajinan bambu, sehingga diharapkan dapat diidentifikasi faktor-faktor yang dapat meningkatkan kinerja usaha kerajinan bambu.

Selain itu, penelitan ini juga dimaksudkan untuk mengetahui sejauh mana bambu yang melimpah di Jawa Barat dan Indonesia dengan berbagai jenis variasi produk telah dimanfaatkan oleh masyarakat sehingga memberi dampak ekonomi pelakunya.

Saung Angklung Udjo termasuk lembaga yang konsisten menjalankan usaha berbasis produk bambu dan dinilai cukup berhasil, maka penelitian ini mengambil kasus Saung Angklung Udjo dengan harapan dapat diketahui secara jelas faktor-faktor yang dapat meningkatkan kinerja Saung Angklung Udjo dan dapat dijadikan model bagi para perajin dalam pengembangan usaha berbasis produk kerajinan bambu.

\section{TINJAUAN TEORI DAN PENGEMBANGAN HIPOTESIS}

\subsection{Konsep Keunikan Sumber Daya}

Affuah (2004) mengungkapkan bahwa keunikan sumber daya adalah sekumpulan aset baik dalam bentuk aset berwujud dan aset tidak berwujud. Aset 
berwujud di antaranya meliputi tanah, sarana fisik, maupun peralatan, sedangkan aset tidak berwujud meliputi SDM (Sumber Daya Manusia), reputasi perusahaan, dan penguasaan informasi dan teknologi.

Seperti terlihat pada Tabel 2, menurut Wheelen dan Hunger (2012), Keunikan atau Kompetensi Sumber Daya dapat diciptakan melalui tiga bentuk aset yakni meliputi aset fisik; tanah, peralatan, dan lokasi, aset SDM; jumlah pegawai dan keahlian, serta aset organisasi yang meliputi budaya dan reputasi. Hill dan Jones (2004), mengemukakan dua kategori sumber-daya perusahaan, yaitu: aset berwujud dan aset tidak berwujud. Sedangkan Collis dan Montgomery (2005), mengemukakan tiga kategori sumber-daya perusahaan industri kreatif, yaitu: aset berwujud, aset tidak berwujud dan kapabilitas organisasi. Kemudian Pearce dan Robinson (2011), mengemukakan bahwa ada tiga sumber daya dasar yang diperlukan oleh pihak perusahaan yakni aset berwujud, aset tidak berwujud, dan kapabilitas organisasi. Aset yang terlihat adalah yang paling mudah diidentifikasi dan dapat ditemukan pada neraca suatu perusahaan, diantaranya yaitu fasilitas produksi, bahan mentah, dan sumber daya finansial. 
Tabel 2.

Konsep keunikan sumber daya

\begin{tabular}{|c|c|c|}
\hline No & Penulis & Konsep \\
\hline 1 & $\begin{array}{l}\text { Pearce dan Robinson } \\
\text { (2011) }\end{array}$ & $\begin{array}{l}\text { Ada tiga sumberdaya dasar yang diperlukan oleh pihak } \\
\text { perusahaan yakni aset berwujud, aset tidak berwujud, dan } \\
\text { kapabilitas organisasi }\end{array}$ \\
\hline 2 & $\begin{array}{l}\text { Wheelen dan Hunger } \\
\text { (2012) }\end{array}$ & $\begin{array}{l}\text { Suatu sumberdaya merupakan aset, competency, process, } \\
\text { skill atau knowledge yang dikendalikan }\end{array}$ \\
\hline 3 & Hill dan Jones (2004) & $\begin{array}{l}\text { Mengemukakan dua kategori sumberdaya perusahaan, } \\
\text { yaitu: aset berwujud dan aset tidak berwujud }\end{array}$ \\
\hline 4 & $\begin{array}{l}\text { Collis dan Montgomery } \\
(1998,2005)\end{array}$ & $\begin{array}{l}\text { Mengemukakan tiga kategori sumberdaya perusahaan } \\
\text { tinggi, yaitu: aset berwujud, aset tidak berwujud, dan } \\
\text { kapabilitas organisasi }\end{array}$ \\
\hline
\end{tabular}

Sumber: Diolah dari berbagai referensi

performance, serta membandingkan

Suatu sumber daya merupakan kelemahan bagi perusahaan apabila sumber daya yang dimiliki perusahaan itu tidak lebih baik dibandingkan dengan pesaing. Wheelen dan Hunger (2012), mengemuka-kan bahwa untuk mengukur apakah suatu sumber daya yang dimiliki perusahaan merupakan kekuatan atau kelemahan dapat dilakukan dengan cara yang dikemukakan David (2004), yaitu dengan menghitung rasio, mengukur dengan periode sebelumnya dan ratarata industri. Cara yang hampir sama dapat dilakukan dengan membandingkan sumber daya itu dengan sumber daya yang dimiliki sebelumnya, sumber daya yang dimiliki pesaing utama dan industri keseluruhan.

Berdasarkan proses penelusuran atas konsep keunikan sumber daya yang ada dalam beberapa referensi serta didukung oleh proses diskusi dengan para perajin bambu dan ahli di 
bidang tersebut, maka diperoleh konstruksi dari variabel keunikan sumber daya seperti di atas, adapun indikator dari masing-masing dimensi tersebut adalah sebagai berikut:

1) Tangible Asset. Pada pe-nelitian ini indikator yang digunakan untuk dimensi Tangible Asset adalah (a) Perangkat kerja (hardware, software, network); (b) Data dan informasi yang tersimpan secara manual maupun digital; (c) Modal kerja; dan (d) Tempat usaha mendukung proses kreatif dan lokasi yang strategis dengan lingkungan bisnis.

2) Intangible Asset. Pada penelitian ini indikator yang digunakan untuk dimensi Intangible Asset adalah (a) Pengalaman perusahaan pada industri kerajinan; (b) Kemampuan beradaptasi dengan lingkungan yang dinamis; (c) Kepemimpinan dan tekad pemilik perusahaan; (d) Reputasi perusahaan; dan (e) Intellectual property, patent, copy right and license.
3) Organization Capability. Pada penelitian ini indikator yang digunakan untuk dimensi Organization Capability adalah (a) Kemampuan teknis dan bisnis pengembang produk; (b) Kemampuan memperoleh dan mengelola pengetahuan; dan (c) Penggunaan product development process.

\subsection{Konsep Strategi Keunggulan}

\section{Bersaing}

Ireland, Hosdkinsson dan Hitt (2009), mengungkapkan bahwa Strategi Bersaing merupakan integrasi dan kordinasi dalam melakukan perancangan komitmen dan tindakan untuk memenangkan persaingan dalam pasar yang bersifat spesifik. Selanjutnya Hubbard dan Beamish (2011), yang menyatakan bahwa Strategi Bersaing adalah bagaimana organisasi mem-posisikan bisnisnya lebih kompetitif dibandingkan dengan industri sejenis lainnya.

Dari komparasi konsep Strategi 
Bersaing di atas, Strategi Bersaing Produk Kreatif Kerajinan merupakan seperangkat tatanan rencana yang sistematis dalam memposisikan produk dipasar yang relatif lebih unggul bila dibandingkan dengan produk pesaing.

\section{Strategi Keunggulan Bersaing} pada umumnya mengacu kepada konsep Porter (1985), di mana dalam Wheelen dan Hunger (2012), menjelaskan dalam persaingan industri perusahaan dalam merumuskan Strategi Bersaing dengan cara melakukan pengembangan dalam lower cost strategy dan differentiation strategy. Dalam literatur tersebut dijelaskan bahwa: "Competitive advantage ultimately results from an effective combination of national circumstances and company strategy. Conditions in a nation may create an environment in which firms can attain international competitive advantage, but it is up to a company to seize the opportunity." Penjelasan bahwa keunggulan bersaing merupakan hasil akhir dari kombinasi yang efektif dari keadaan secara keseluruhan dan merupakan strategi bersaing suatu perusahaan. Kondisi ini dapat menciptakan suatu keadaan dimana perusahaan dapat mencapai keunggulan bersaing secara lebih luas lagi hingga di tingkat internasional serta memiliki peluang yang baik dan untuk itu perusahaan harus memiliki Strategi Bersaing yang tepat.

\subsection{Konsep Market Commitment Model}

\section{Market Commitment Model}

$(M C M)$, adalah model strategi dari

Michael De Kare-Silver (1997), dalam

bukunya Strategy in Crises. Strategi ini mengacu pada berbagai penelitian yang pernah dilakukan menyangkut strategi dan hasil penelitiannya sendiri di berbagai perusahaan, kemudian menyimpulkan bahwa lingkungan bisnis saat ini telah berubah, banyak CEO yang tidak menjalankan tugasnya dalam penetapan strategi, dan banyak 
perusahaan yang skeptis terhadap strategi, sebagai gantinya lebih berfokus kepada inward-looking process improvement. Untuk sampai kepada kesimpulan tersebut, Michael DKS antara lain mendasarkan kepada hasil penelitian yang dilakukan oleh Kalchas Group (1996), yang menguji efektifitas beberapa pendekatan formulasi strategi dengan 7 kriteria, yaitu reflecting the business realities of the late 1990s, starting with customer, rooted and immersed in market understanding, practical (not teoritical), specific (not superficial), encouraging a longer-term view, and measurable.

Memahami bahwa 7 (tujuh) kriteria tersebut sangat penting bagi $a$ powerfull strategy maka Michael DKS berusaha untuk memenuhi kriteria tersebut melalui MCM. MCM yang diunggulkan sebagai salah satu model formulasi strategi menjelang millennium ke-3, memandang customer sebagai sources of advantage disertai dengan wawasan jauh ke depan dan komitmen kepada pasar atau future intent. 


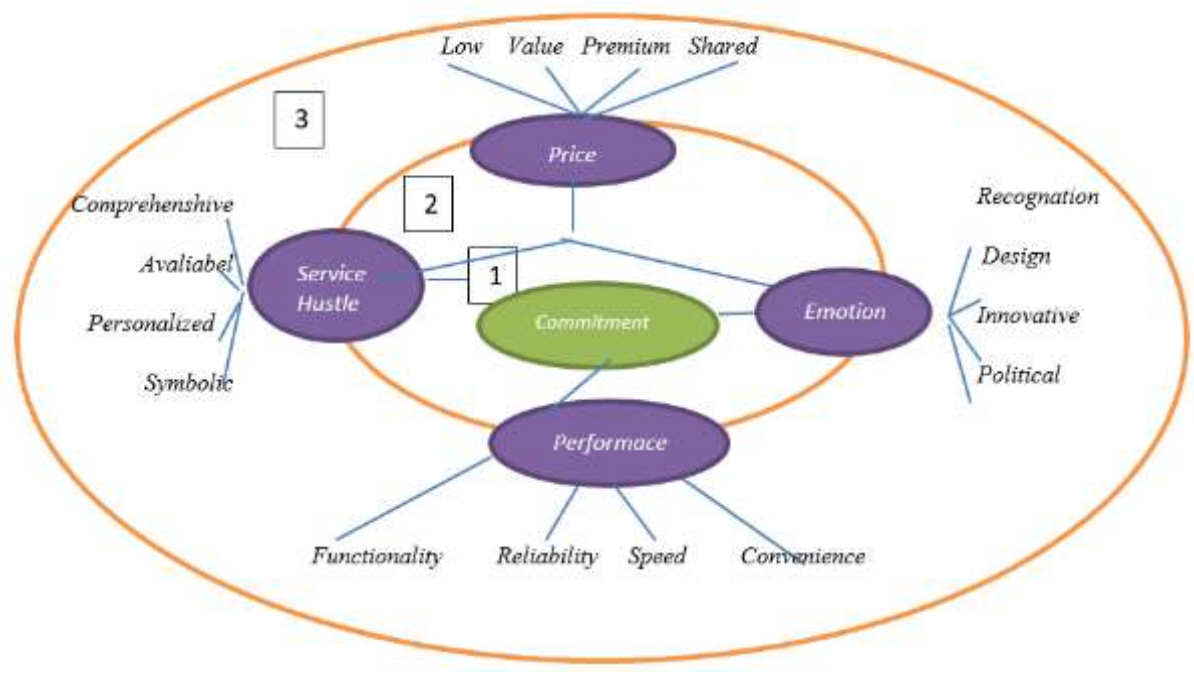

Gambar 1. The market commitment model

Sumber : Silver, (1997: 60 ) "Strategy in Crisis" dalam Triaji, “ Market Commitment Model: Alternatif Strategi Bagi Perbankan di Indonesia" (Tanpa tahun: 10), Triaji, "Peranan Non Financial Performance dalam Menentukan Efektifitas Strategi Menggunakan Market Commitment Model di Perbangkan Indonesia (Tanpa Tahun: 3)

MCM pada dasarnya terdiri dari 3 (tiga)

dimensi yaitu commitment, the four prime axis or forms of competitive advantage, and the underlying sources of that competitive advantage. Model ini harus dilihat secara keseluruhan dan selalu dilakukan evaluasi, karena hal tersebut merupakan batu loncatan di dalam menemukan dan mengembangkan daya saing perusahaan sepanjang waktu dan unggul di pasar.

\section{Dimensi ke-1:Commitment}

Komitmen mempunyai arti bahwa perusahaan memiliki perhatian yang sangat besar terhadap pasar dimana perusahaan bersaing. Hal ini merupakan faktor terpenting dan dasar dalam menciptakan kesuksesan perusahaan sepanjang waktu. Komitmen yang efektif terdiri dari dua unsur yaitu pertama, mengembangkan suatu pemahaman dan pengetahuan yang mendalam mengenai customer sesuai target market (deep-rooted market immersion) dan kedua, membangun suatu pandangan jauh ke depan dan bertekad untuk keluar sebagai pemenang dalam persaingan 
(the long term horizon and determination to win).

Dimensi ke-2: Empat sumbu utama sumber keunggulan perusahaan

Dalam dimensi ini terdiri dari 4 (empat) sumber keunggulan daya saing perusahaan yaitu price, emotion, performance, dan service hustle. Secara bersama-sama hal tersebut memberikan satu kelompok pilihan strategi yang cukup komprehensif yang dibutuhkan perusahaan untuk menerjemahkan komitmennya ke dalam strategi yang efektif dan continue sepanjang waktu terhadap target pasar yang telah ditetapkan.

\section{Dimensi ke-3: Indikator sumber}

\section{keunggulan bersaing perusahaan}

Keempat sumber keunggulan
tersebut dapat saling melengkapi
dan mem-perkuat satu sama lain,
menyatukan kinerja yang terbaik
(performance) dari produk atau jasa
perusahaan, menjual produk atau jasa
pada harga

menguntungkan bagi perusahaan (price), disertai dengan pelayanan yang sangat bagus (servicehustle) dan didukung oleh unsur-unsur emosi (emotional values) dari produk atau jasa perusahaan. Prinsip tersebut harus senantiasa diperhatikan dan di evaluasi dan peluang yang mungkin ada selalu dikembangkan dan dicari untuk menambah daya saing guna mempengaruhi customer untuk membeli produk dan jasa perusahaan.

\section{Konsep Kinerja Bisnis}

Pada dasarnya Kinerja Bisnis merupakan output atau hasil dari penerapan segala aktivitas yang berhubungan dengan pemasaran. Biasanya, kinerja pemasaran hanya dilihat melalui kinerja keuangan perusahaan. Namun, Best (2009) melengkapi bahwa untuk kinerja keuangan bisnis, perusahaan memerlukan serangkaian pengukuran yang paralel untuk mengikuti kinerja pemasaran. Walaupun pengukuran 
tersebut tidak memiliki relevansi dengan akuntansi keuangan, secara individu dan kolektif menyediakan pandangan kinerja pemasaran yang berbeda dan lebih strategis. Dalam laporan kinerja pemasaran terdapat informasi mengenai pertumbuhan pasar, pangsa pasar, retensi konsumen, pelanggan baru, pelanggan yang tidak puas, kualitas produk relatif, kualitas layanan relatif, dan penjualan produk baru relatif.

Penilaian Kinerja Bisnis dapat dilihat dari dua sisi, yaitu sisi keuangan dan sisi non keuangan. Dalam penelitian bisnis, kinerja lebih ditekankan pada kinerja keuangan, namun demikian sisi non keuangan pun akan dilihat. Penilaian kinerja keuangan merupa-kan sesuatu yang penting karena merupakan konsekuensi dari suatu keputusan ekonomi yang diambil dan suatu tindakan ekonomi. Kinerja keuangan menunjukkan perencanaan, implementasi serta evaluasi pelaksanaan strategi yang tercermin dari sasaran yang dapat diukur seperti ROI (Return on Investment), ROE (Returnof Equity) ataupun ROA (Return on Assets). Berdasarkan penelusuran terhadap konsep Kinerja Bisnis, maka diperoleh variabel Kinerja Bisnis dengan indikator dari masing-masing dimensi sebagai berikut:

1) Pertumbuhan penjualan (Sales

Growth) adalah pertumbuhan penjualan yang dicapai dalam periode waktu tertentu. Pertumbuhan penjualan juga digunakan untuk mengukur tingkat efektivitas penjualan perusahaan, menilai biaya, kon-tribusi keuntungan, tingkat pengembalian modal, dan sisa dari keuntungan.

2) Pangsa pasar (Market Share) merupakan besarnya bagian atau luasnya total pasar yang dapat dikuasai oleh suatu perusahaan yang biasanya dinyatakan dengan persentase. Pangsa pasar juga merupakan bagian pasar yang dapat diraih oleh perusahaan, di mana pangsa pasar menjadi salah satu 
indikator meningkatnya kinerja

pemasaran suatu perusahaan, dimana

pengukurannya adalah tingkat

persentase pasar aktual yang dikuasai

dari total populasi pasar aktual yang

ada.

3) Profitabilitas (Profitability) merupakan kemampuan suatu perusahaan untuk mendapatkan laba (keuntungan) dalam suatu periode tertentu atau dengan kata lain kemampuan suatu perusahaan dalam menghasilkan keuntungan pada tingkat penjualan, aset, dan modal saham tertentu. Jadi pada intinya profitabilitas merupakan kemampuan perusahaan menghasilkan laba yang akan menjadi dasar pembagian dividen perusahaan. Dimana dalam hal ini diukur pula ROA (Return on Assets), ROE (Return on Equity), serta tingkat likuiditas dan solvabilitas unit bisnis.

\section{METODE RISET}

Penelitian ini menggunakan desain kualitatif dengan metode studi kasus, untuk mengetahui dan menjelaskaan bagaimana keunikan sumber daya yang dimiliki serta keunggulan bersaing Saung Angklung Udjo Bandung dilihat dari teori market commitment model sekaligus menganalisis faktor-faktor yang mempengaruhinya.

Data yang dibutuhkan peneliti, diambil dari sumber antara lain: Manajemen Saung Angklung Udjo, Pegawai dan pengunjung serta dokumen-dokumen sekunder sesuai tujuan penelitian. Instrumen untuk pengumpulan data menggunakan alat bantu berupa: pedoman wawancara, alat perekam, camera (photo).

Teknik pengolahan dan analisis data dilakukan sebagai berikut: mengorganisasikan data; Pengelompokan berdasarkan kategori, tema dan pola jawaban, menguji asumsi atau permasalahan yang ada terhadap data; 
mencari alternatif penjelasan bagi data; menulis hasil penelitian.

Penulisan data subjek yang telah berhasil dikumpulkan merupakan suatu hal yang membantu peneliti untuk memeriksa kembali apakah kesimpulan yang dibuat telah selesai. Penulisan yang dipakai dalam penelitian ini adalah deskripsi data berdasarkan wawancara mendalam dan observasi dengan subjek serta significant other.

Proses dimulai dari data-data yang diperoleh dari subjek dan significant other dengan acuan teori market commitment model (MCM), dibaca berulang kali sehinggga penulis mengerti benar permasalahanya, kemudian dianalisis, sehingga didapat gambaran mengenai penghayatan pengalaman dari subjek. Selanjutnya dilakukan interprestasi secara keseluruhan, dimana di dalamnya mencangkup keseluruhan kesimpulan dari hasil penelitian.

\section{PEMBAHASAN}

Deskripsi hasil penelitian dari Manajemen dan customer, antara lain Taufik Hidayat Udjo, sebagai Manajer Umum, Mutiara Deciana Udjo, sebagai Direktur Operasional, Kang Bawi dan Asep sebagai perwakilan dari pegawai. Adapun untuk customer diambil dari pengunjung secara acak sesuai tujuan penelitian berkaitan dengan keunikan sumber daya, keunggulan yang dimiliki dan pencapaian yang diperoleh Saung Angklung Udjo dapat dikemukakan sebagai berikut:

\section{A. Keunikan Sumber Daya Saung Angklung Udjo \\ 1) Tangible Asset}

Aset berwujud yang dimilki oleh Saung Angklung Udjo berupa perangkat kerja sudah lengkap, mulai dari bangunan secara fisik sesuai fungsi peruntukannya, walau menurut pihak manajemen masih terus ditingkatkan kuantias dan kualitasnya. 
Aset berupa data dan informasi pengunjung, data rekanan dan semua jenis data sudah lengkap dan tersimpan dengan rapi berupa hard copy dan soft copy. Sehingga apabila sewaktu-waktu dibutuhkan, mudah diperoleh dengan cepat.

Aset berupa modal kerja pun dianggap memadai, contoh dalam hal angklung yang akan dimainkan oleh sejumlah pengunjung sudah tersedia. Lahan parkir luas menapung sampai 20 bus dan 30 mobil kecil, termasuk 200an motor. Tempat usaha mendukung kelancaran berbagai kegiatan, selain strategis, fasilitas pendukunnya pun memadai

\section{2) Intangible Asset}

Aset tidak berwujud dari sisi pengalaman operasi, sudah lebih dari 40 tahun. Artinya memiliki pengalaman yang mumpuni dan khas. Kemampuan perusahaan beradaptasi dalam lingkungan bisnis industri kreatif telah ditunjukkan dan mampu meyakinkan pihak lain untuk mendukung operasional sehingga telah terjalin kerjasama dengan berbagai pihak: Pemerintah, Swasta, Pendidikan dan Komunitas.

Komitmen pemimpin, dalam hal ini manajemen dan direksi untuk mengupayakan peningkatan kredibilitas, dalam kategori sangat berkomitmen, terbukti dengan perjuangan untuk bekerja optimal sehingga di tahun 2010 mendapatkan pengakuan UNESCO, dan pada saat ada kegiatan kenegaraan, seperti KAA 2015 ia termasuk salah satu icon budaya Indonesia, budaya Sunda, “Angklung Udjo adalah milik bangsa Indonesia, khas budaya Sunda."

Saung Angklung Udjo mampu membangun reputasinya, sehingga dunia mengenal Indonesia melalui Angklung Udjo-Sunda- Bandung. Copyright, patent, licence telah dimiliki oleh Saung Angklung Udjo. Brand Image-nya telah mendunia. 


\section{3). Organizational Capability}

Berkaitan kompetensi Saung

Angklung Udjo dalam mengelola kemampuan teknis cukup berkompeten, karena kegiatan ini sudah spesialisasinya dan khas. Untuk bisnis pertunjukan Angklung Udjo berada pada tahap profesional, namun untuk pengelolaan pengembangan bisnis item atau variasi produk kerajinan bambu selain produk angklung masih kurang. Perusahaan dalam hal memperoleh dan mengelola pengetahuan, untuk produk Angklung dan Pertunjukkan Angklung sudah memadai.

\section{Strategi Market Commitment}

\section{Model (MCM)}

Kinerja bisnis Saung Angklung Udjo dari sisi financial sulit didapat, maka peneliti mengarah kepada ukuran kinerja dari sisi non financial. Strategi yang disusun dengan menggunakan Market Commitment Model memiliki "toolkit" sistem pengukuran kinerja yang sifatnya non financial measurement.
Pada dasarnya sistem pengukuran kinerja ini akan melihat sejauh mana 4 keunggulan daya saing (dimensi 2) dan 16 indikator sumber keunggulan perusahaan (dimensi ke 3 dari $\mathrm{MCM}$ ) telah sesuai dengan strategi yang ditetapkan. Karena strategi MCM pada dasarnya ditujukan untuk "immerse" dengan pasar dan customer, maka untuk melakukan pengukuran kinerja MCM secara objektif harus dilakukan investigasi dan penelitian secara mendalam kepada customer. Ada 10 elemen yang dapat digunakan sebagai alat ukur dan monitoring strategi MCM, yaitu sebagai berikut:

\section{Market and customer immersion}

Elemen ini menguji sejauh mana sumber keunggulan bersaing Saung Angklung Udjo di mata customer. Hal ini menghasilkan data tentang unsur keunggulan bersaing (competitive advantage) yang dianggap penting oleh customer, mendorong pembelian, dan tetap loyalnya customer agar tidak pindah ke pesaing lain. Secara 
jelas dapat dilihat pada gambar 2 di bawah ini.

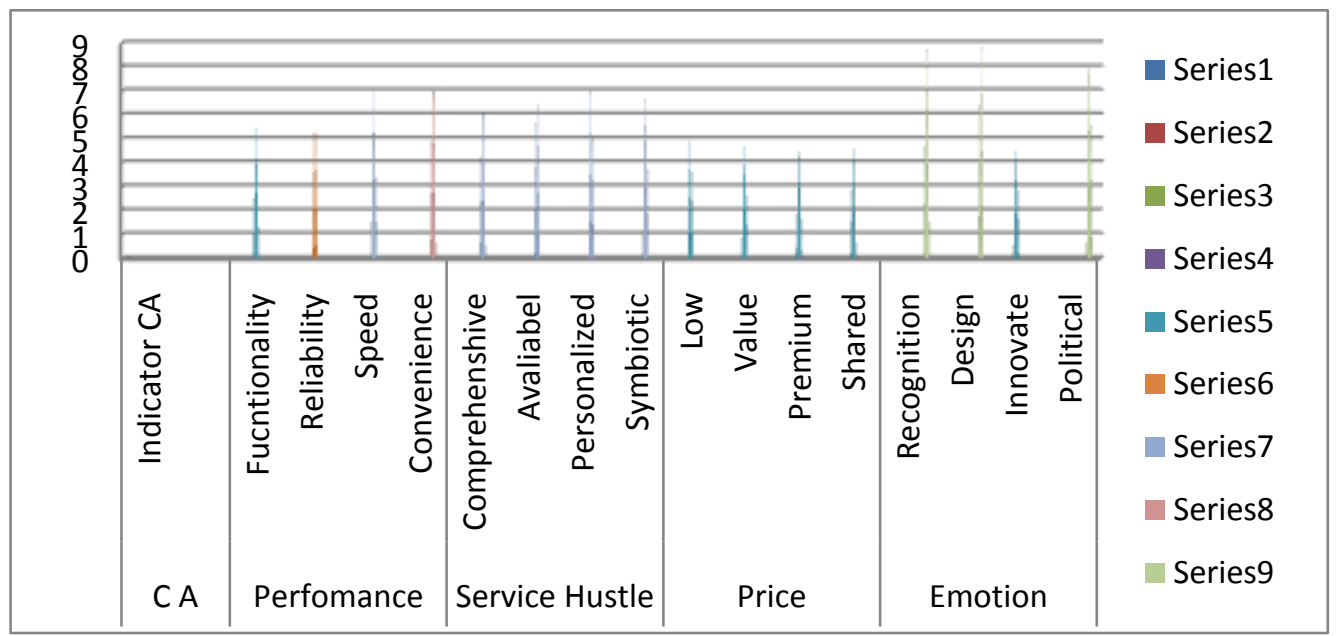

Gambar 2. Apa yang dianggap paling penting oleh customer

Dari gambar di atas di peroleh hasil bahwa customer menganggap bahwa yang paling penting dari produk kreatif bambu Saung Angklung Udjo adalah keunggulan dari sisi emosi terutama dalam hal recognisi dengan skor 9 dan political will dengan skor 8 .

\section{Identifying advantage}

Melihat sejauh mana seluruh sumber keunggulan bersaing perusahaan bila dibandingkan dengan para pesaing di mata customer dan berapa besar angka perbedaannya.
Alat ukur yang menghitung perbedaan ini seringkali disebut sebagai Competitive Advantage Gap (CAG). Jika CAG positif maka keunggulan daya saing perusahaan lebih baik dibanding pesaing, negatif berarti keunggulan daya saing perusahaan lebih jelek dibanding pesaing, dan nol berarti perusahaan memiliki keunggulan daya saing yang sama kuat dengan pesaing. CAG ini sangat penting, karena dengan mengetahui besarnya CAG akan sangat menentukan bagi pengembangan strategi berikutnya sekaligus dalam menentukan 
investasi yang diperlukan. Secara lebih jelas lihat gambar 3.

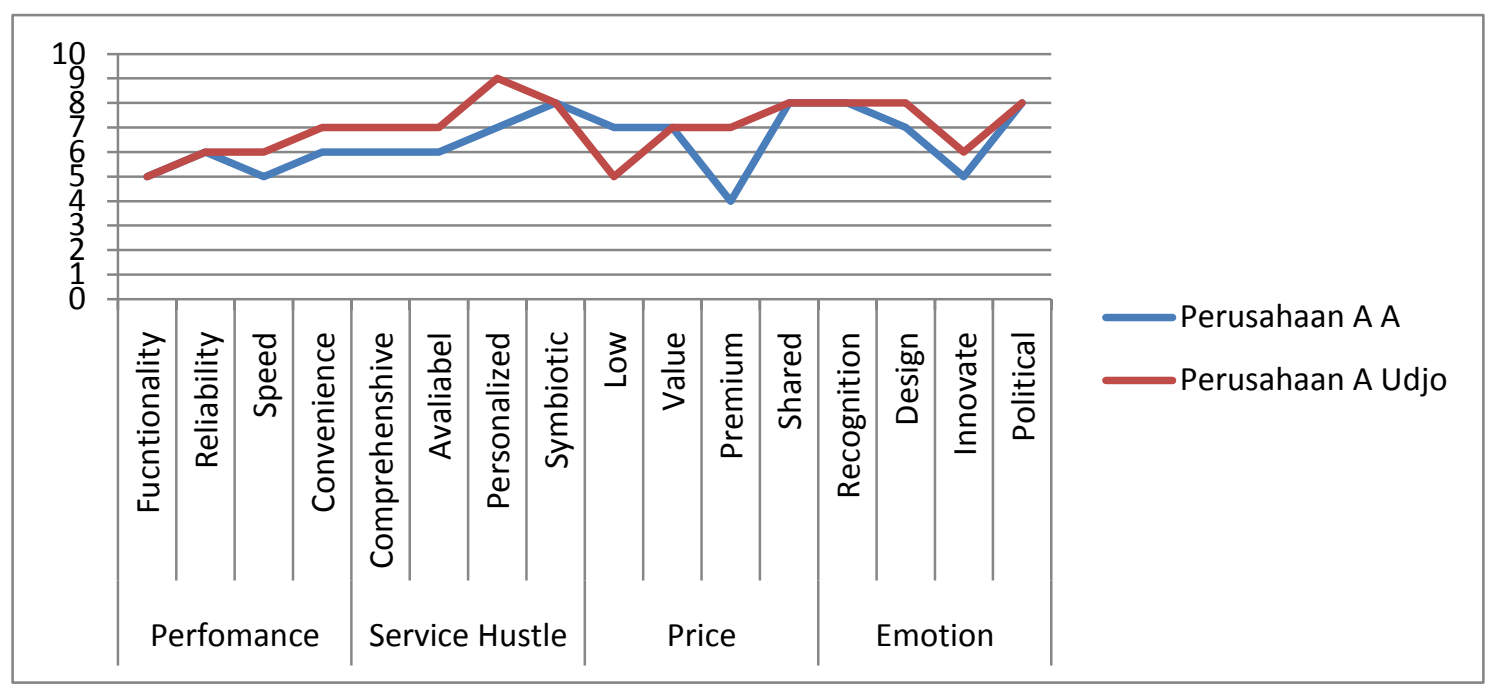

Gambar 3. Angka perbedaan dengan perusahaan sejenis

Saat informan diminta menilai, perusahaan sejenis adalah sesuai persepsi konsumen tidak ditentukan oleh peneliti dan diminta membandingkan dengan Saung Angklung Udjo, hasilnya sebagaimana tergambar di atas. Performance SAU posisi lebih tinggi dibanding perusahaan sejenis, dan item Service hustle dengan indikator personalized lebih tinggi, skor nilai 9 dan dalam indikator price item low-price terlihat di bawah, skor nilai 5 .

\section{Segmentation}

$$
\text { Mengetahui sejauh mana }
$$

segmentasi yang telah dibuat perusahaan efektif. Customer akan menilai berbagai segmen pasar perusahaan dan menilai berapa besar angka perbedaannya di antara segmen tersebut. Hal ini penting untuk mengetahui mana segment pasar yang lemah dan mana yang kuat. Pada segment pasar yang besar, menguntungkan, dan cukup menarik, perusahaan dapat lebih memfokuskan strateginya pada segment pasar tersebut.

\section{Saung Angklung Udjo telah} membuat segmentasi untuk pasar, antara lain instansi pemerintah, sekolah-sekolah 
dari tingkat PG, SD, SMP dan SMA, pihak swasta dengan hotel, biro perjalanan wisata dan lembaga bisnis lainnya serta masyarakat umum. Hasil menunjukkan bahwa pihak masyarakat dan swasta memberikan penilaian tinggi dalam hal reliability dan personalized, skor 8. Pihak sekolah dan pemerintah menilai tinggi faktor share price dan recognition dengan skor nilai 8 . Secara lebih lengkap lihat Gambar 4 di bawah ini:

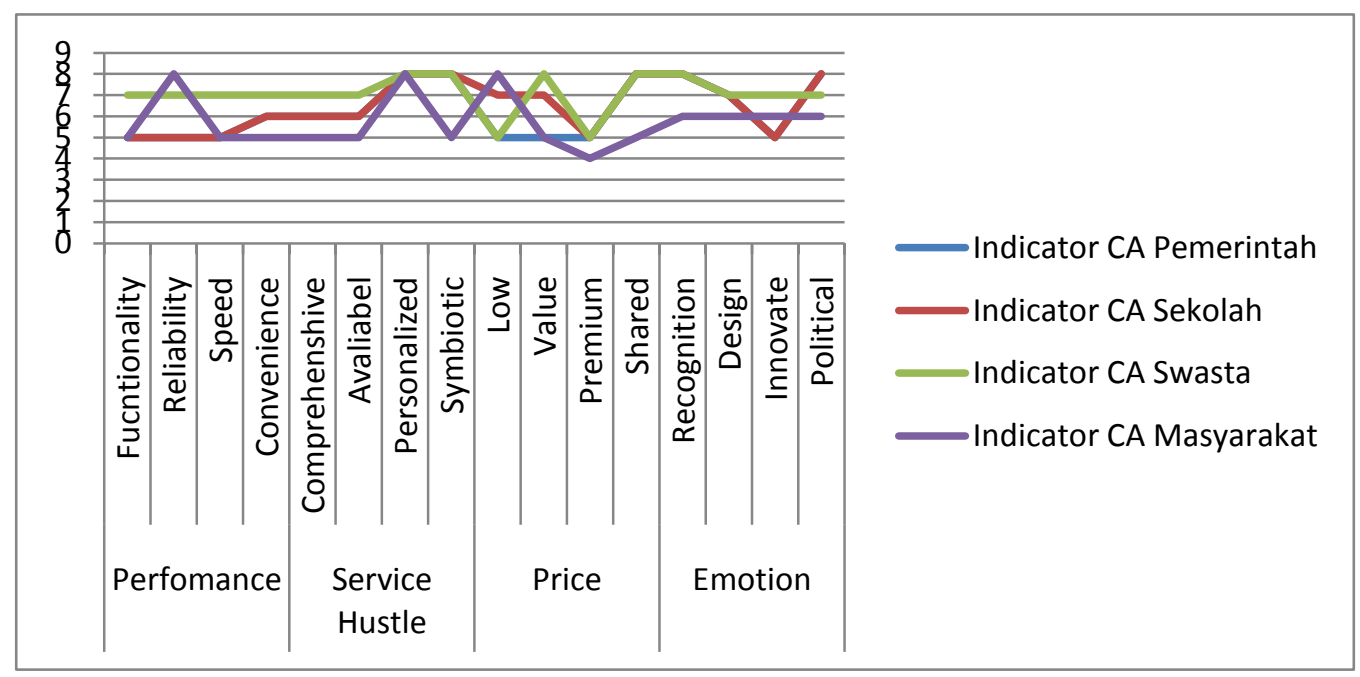

Gambar 4. Segmentasi yang dibuat oleh SAU dalam menjalankan usaha

\section{Summarise the competitive situation}

Berdasarkan hasil evaluasi pasar dan segmentasi oleh customer maka dapat disimpulkan kondisi daya saing perusahaan. Hal-hal yang diukur adalah apa yang menjadi prinsip dan yang paling 
dianggap sebagai keunggulan perusahaan oleh customer, berapa besarnya CAG dan pengaruhnya (significance) terhadap pembelian customer, apa saja kelemahan perusahaan dan pengaruhnya serta apa yang seharusnya dilakukan perusahaan jika memang ada kelemahan. Selengkapnya lihat Gambar di bawah menunjukkan persepsi konsumen atas kekuatan dan kelemahan SAU, antara lain dapat dilihat bahwa SAU pada umumnya dipersepsi memiliki kekuatan di atas perusahaan sejenis, karena kenyataannya secara brand, telah mendunia, unik dan khas. Perpaduan dari item-item kreatif, bukan hanya produk fisiknya, tetapi nilai seni dan budaya yang dikandung di dalamnya. Kelemahannya dalam hal kecepatan dan symbiotic serta harga tidak bisa dijadikan premium, karena ini adalah produk angklung dan seni pertunjukkannya memerlukan banyak orang, masal.

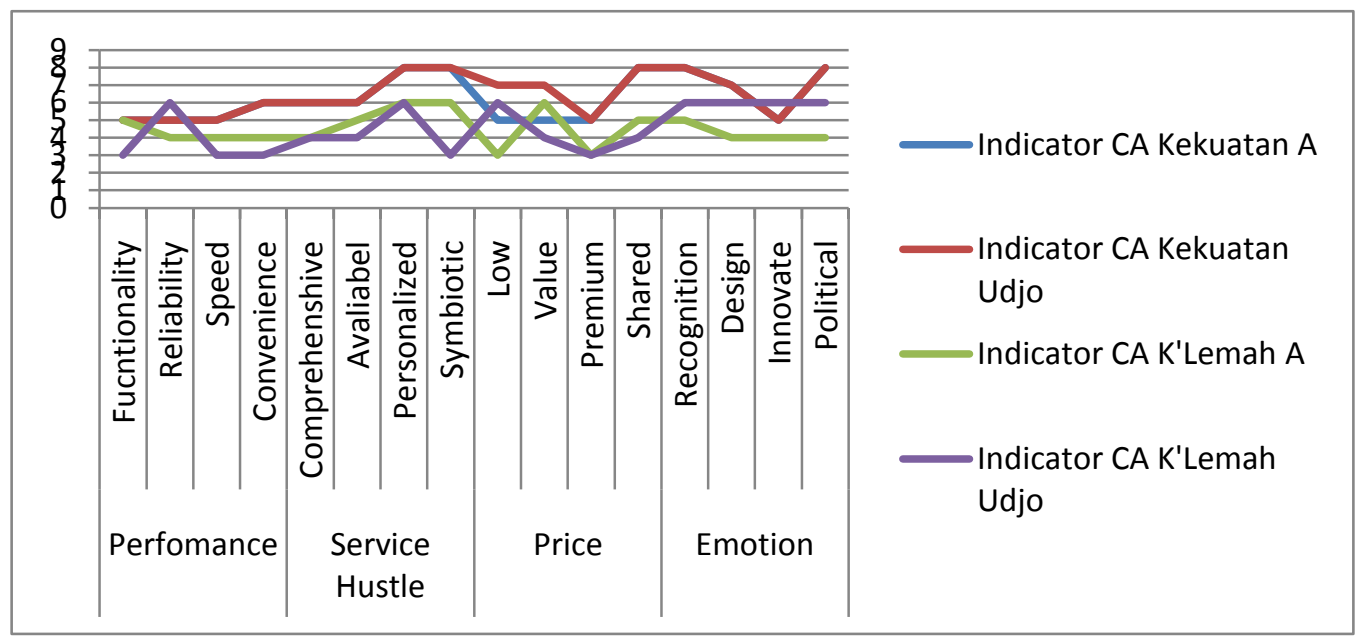

Gambar 5. Kekuatan dan kelemahan pasar SAU dibanding perusahaan lain 


\section{Sustainability}

Mengetahui sejauh mana berbagai keunggulan yang telah diidentifikasi mampu untuk terus ditingkatkan dan jika yakin terhadap pemahaman pasar dan target customer, berapa besar investasi sumber daya yang diperlukan. Selengkapnya lihat pada gambar 6 di bawah ini:
Dalam berbagai hal indikator perubahan akan kebutuhan konsumen dipersepsikan sangat tinggi oleh konsumen, namun SAU juga masih dapat meningkatkan keunggulan apabila memperhatikan faktor-faktor yang dibutuhkan konsumen dan mengimbangi kemajuan teknologi yang ada. Keunggulan SAU terlihat dari sisi service

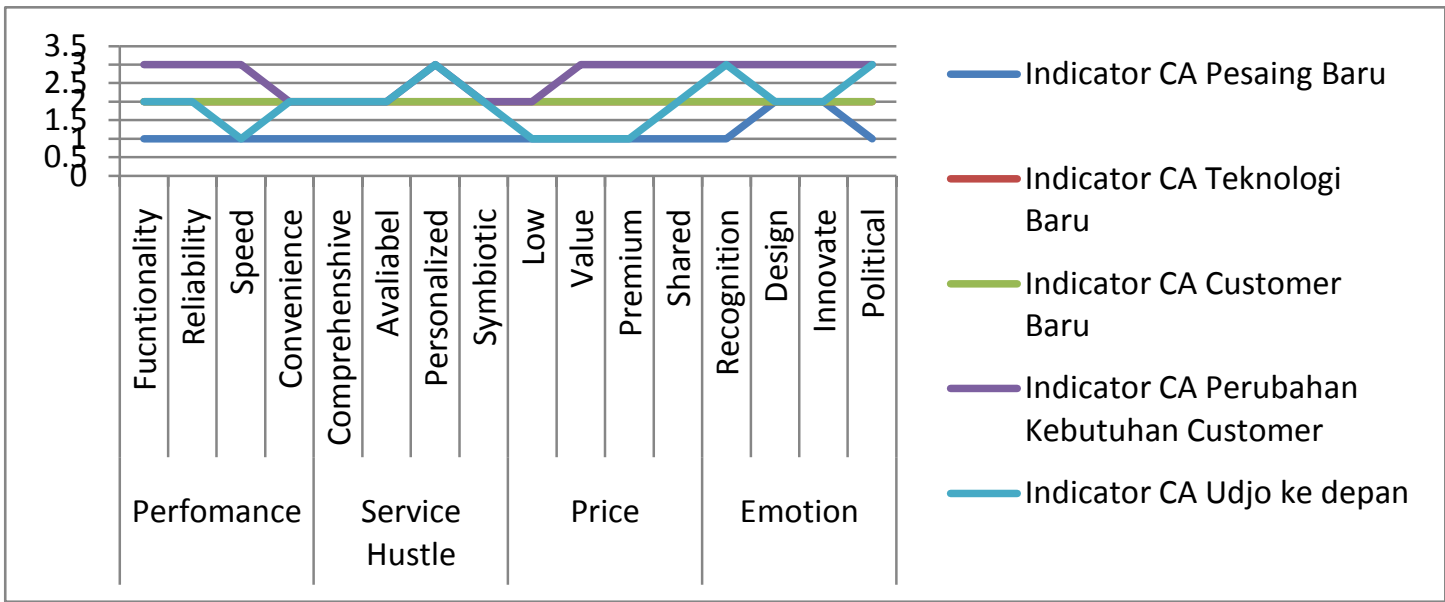

Gambar 6. Kemungkinan SAU dapat meningkatkan daya saing ke depan

hustle dengan indikator personalized dan dari sisi emosi indikator recognisi dan political.

\section{Trends}

CAG bukanlah alat ukur yang sifatnya statis, tetapi dapat dijadikan alat yang dinamis untuk mengukur kinerja perusahaan selama berjalan.

Karena yang lebih penting untuk diketahui sebenarnya tidak hanya kinerja perusahaan saat ini, tetapi yang lebih penting adalah bagaimana trend kinerja perusahaan selama 3 tahun terakhir, naik atau turun. Dari hasil tersebut dapat 
digunakan untuk mengetahui efektifitas strategi yang telah dilakukan selama ini, strategi baik/buruk, atau nilai CAG tersebut sebagai akibat dari tindakan pesaing perusahaan. Selanjutnya apa yang harus dilakukan untuk meningkatkan daya saing perusahaan di masa datang. Selengkapnya dapat dilihat pada gambar 7 di bawah ini:

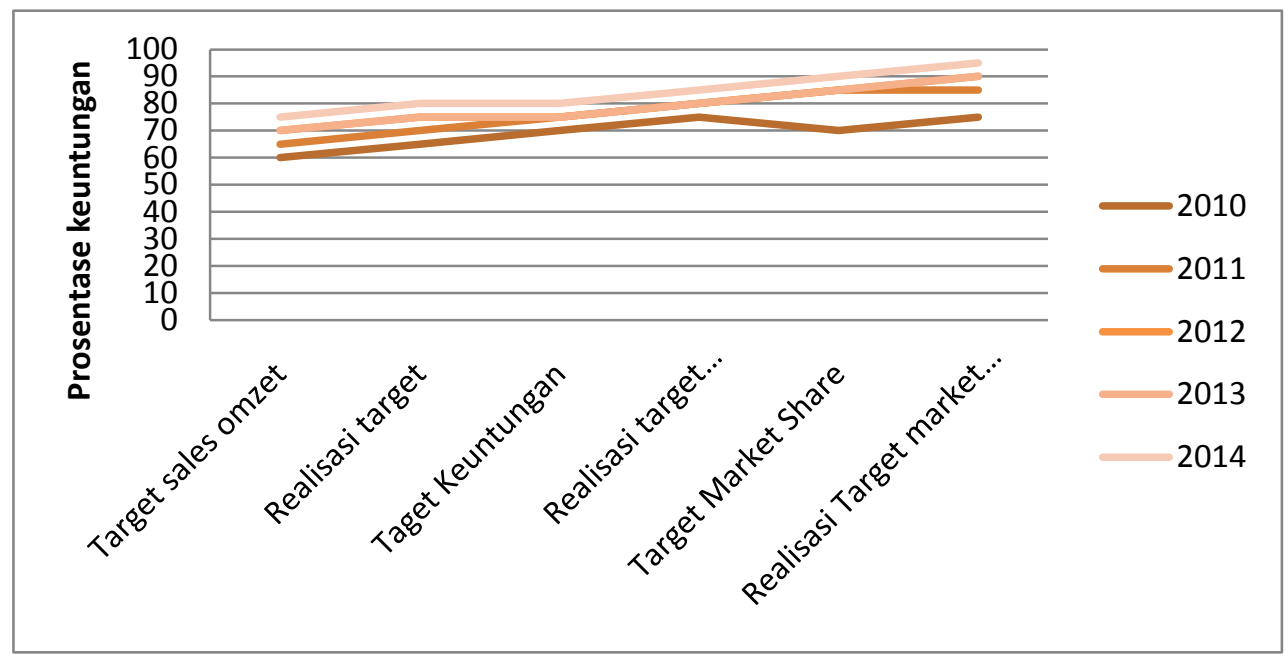

Gambar 7. Pencapaian target perusahaan 5 tahun terakhir

Gambar di atas menunjukkan prosentase antara target yang ditentukan dan keuntungan yang diperoleh, hasilnya menunjukkan tren naik dari tahun ke tahun. Untuk itu SAU masih dapat memiliki keunggulan bersaing.

\section{Organisation gaps}

Mengetahui sejauh mana kemampuan organisasi dapat menciptakan keunggulan daya saing sesuai dengan tuntutan pasar.

Organization gaps juga dapat mengukur sejauh mana perusahaan mampu memenuhi tuntutan pasar secara lebih baik dibandingkan dengan para pesaingnya. 
Kemampuan organisasi ini antara Selengkapnya lihat pada tabel 4 di lain adalah skills, systems, structure, bawah ini:

operations, resources, dan investment.

Tabel 4.

Daftar gap organisasi

\begin{tabular}{|c|c|}
\hline Keahlian & $\begin{array}{l}\text { Sudahkan perusahaan memperoleh keahlian yang sesuai untuk memberikan } \\
\text { produk/jasa yang terbaik seperti yang diinginkan customer? Untuk manajemen SAU, } \\
\text { sudah dimiliki dan terus dijaga untuk dikembangkan. }\end{array}$ \\
\hline Sistem & $\begin{array}{l}\text { Apakah sistem yang ada dapat membantu tujuan yang ingin dicapai perusahaan? } \\
\text { Sistem kerja di SAU juga sudah dirancang dan selalu menuju kea rah yang lebih } \\
\text { baik. }\end{array}$ \\
\hline Struktur & $\begin{array}{l}\text { Apakah organisasi (diantara fungsi dan unit kerja lainnya) berjalan secara harmonis } \\
\text { dan efektif menuju tujuan yang sama? Manajemen sudah membuat struktur dan } \\
\text { organisasi kerja yang harus dipedomani oleh semua pegawai. }\end{array}$ \\
\hline Operasi & $\begin{array}{l}\text { Apakah yang kita lakukan saat ini sudah cukup efisien dalam hal biaya seperti yang } \\
\text { kita inginkan? Manajemen SAU masih memperbaiki system operasi agar efisiensi } \\
\text { dapat tercipta dan memberikan keuntungan yang signifikan. }\end{array}$ \\
\hline $\begin{array}{l}\text { Sumber } \\
\text { Daya }\end{array}$ & $\begin{array}{l}\text { Apakah sumber daya yang ada sudah mencukupi untuk saat ini atau untuk waktu yang } \\
\text { akan datang? Sumber daya di SAU saat ini cukup, namun ke depan perlu peningkatan } \\
\text { sesuai dengan perkembangan kebutuhan. }\end{array}$ \\
\hline Investasi & $\begin{array}{l}\text { Apakah kita harus membeli sumber daya tambahan, sebagai contoh melalui aliansi } \\
\text { atau akuisisi? Mampukah kita membiayai apa yang kita butuhkan? } \\
\text { Manajemen SAU berusaha menyisihkan dari sebagian pendapatan untuk investasi, } \\
\text { seperti dengan perluasan lahan operasi dan juga lahan penunjang berupa lahan untuk } \\
\text { menanam kebun bambu. }\end{array}$ \\
\hline
\end{tabular}




\section{Looking to the future}

Mengetahui sejauh mana $C A G$ trend di masa yang akan datang (5 tahun ke depan) dan sumber keunggulan apa yang dapat digunakan untuk memenuhinya. Hal ini disebabkan antara lain karena kebutuhan customer semakin demanding, posisi daya saing perusahaan pasti akan berubah, munculnya pesaing yang berbeda, dan kemungkinan munculnya teknologi baru. Oleh karena itu, perusahaan harus selalu melihat kembali pentingnya pemahaman yang mendalam terhadap pasar dan menerapkan pendekatan Triple-I (immersion, intuition, and innovation), agar selalu dapat menemukan competitive advantage yang baru. Untuk poin ini, manajemen Saung Angklung Udjo berusaha selalu optimis bahwa ke depan harus semakin maju mengikuti perkembangan zaman dengan tetap mengusung budaya lokal "Sunda".

\section{Stakes in the ground}

Mengetahui seberapa jauh target segmen pasar yang ada telah secara efektif dikuasai dan berapa besar nilai CAG-nya di antara segmen pasar dilihat dari dimensi ke-2 dan ke-3 dari MCM. Sehingga dapat disimpulkan segmen pasar mana yang sangat penting bagi perusahaan, segmen pasar mana yang merupakan ambisi perusahaan, segmen pasar mana yang akan dituju, dimana posisi perusahaan berikutnya, dan berapa besar investasinya. Disamping itu, dengan angka ini dapat digunakan untuk mendorong motivasi dan orientasi seluruh pegawai ke masa depan. Manajemen SAU dalam melihat target segmen adalah semua kalangan, karena yang utama adalah misi budaya, mengangkat seni tradisional sunda. Artinya, fokusnya bukan segmen pasar, tapi produk angklung dan kualitas seni pertunjukan musik angklung.

\section{Exploination}

Setelah skor dari semua angka CAG dari 4 keunggulan bersaing dan 16 unsur 
sumber keunggulan bersaing perusahaan

diketahui, maka tahap berikutnya adalah menyusun tindakan pemanfaatan peluang perusahaan. Sebagai contoh, beberapa pilihan tindakan pemanfaatan peluang tersebut antara lain menyangkut revenue (meningkatkan sales dan market share), pricing (menaikkan/menurunkan harga, mengurangi discount), invesment (meningkatkan promosi, investasi untuk meningkatkan sumber keunggulan tertentu), costs (mengurangi biaya promosi, mengawasi secara ketat jadwal pembayaran debitur), dan customer (menetapkan basis pengembangan loyalitas).

Manajemen Saung Angklung Udjo belum mengidentifikasi keseluruhan nilai CAG secara detail, namun pada dasarnya dari 16 indikator sumber keunggulan bersaing market commitment model sudah dijalankan dan pada tindakan exploitation dalam arti menyusun rencana pengembangan untuk masa yang akan datang dilakukan oleh tim Research and
Development $(R \& D)$ Saung Angklung Udjo sebagai divisi pengembangan usaha/bisnis. Kinerja Bisnis Saung Angklung Udjo Gambaran tentang kinerja Saung Angklung Udjo dapat dideskripsikan sebagai berikut:

Saung Angklung Udjo dari tahun ke tahun menunjukkan peningkatan cukup baik dikarenakan manajemen SAU selalu berusaha untuk memperbaiki kualitas sarana prasarana, layanan dan tentu kualitas event yang dilakukan.

Data pengunjung setiap hari ada pada kisaran 20 bus Pariwisata untuk waktu kunjungan pagi, siang, dan sore, rata-rata untuk satu bus jumlah penumpang 48 orang termasuk supir dan guide, ditambah mobil pribadi, kunjungan keluarga atau perorangan, rata-rata sehari 10 mobil, jumlah pengunjung permobil pribadi minimal 2 orang.

Berkenaan dengan penentuan target, baik dalam bentuk omset pendapatan atau jumlah pengunjung, manajemen SAU menyatakan selalu 
melakukan evaluasi atas berbagai hal, termasuk dalam target pengunjung yang berdampak pada penghasilan yang diperoleh.

Menurut Mutiara Deciana Udjo, selama lima tahun, mulai dari tahun 2010 sampai sekarang 2014 target yang ditentukan tercapai dengan cukup memuaskan, hal ini dikarenakan manajemen SAU dalam menentukan target dalam kategori realistis, "Alhamdulillah target yang ditentukan tidak terlalu meleset. Dapat dikatakan tercapai, walau belum sepenuhnya sesuai dengan harapan ideal. Misalnya kami tentukan ada peningkatan pengunjung sampai $5 \%$ atau $10 \%$ persen, tiap bulannya. Ada kalanya, jumlahnya masih sama dengan bulan sebelumnya, atau malah dibandingkan dengan bulan pada tahun lalu, ada penurunan. Itu, bagi kami biasa."

Pemasaran atau promosi yang dilaksanakan, bahwa SAU melakukan kegiatan promosi bekerja sama dengan berbagai pihak seperti pemerintah dan swasta, antara lain dengan Dinas Pariwisata, ASITA, Perhotelan dan Birobiro perjalanan wisata dan perbankan. Untuk promosi kepada lembaga pendidikan, hampir seluruh sekolah di Jawa Barat dari tingkat PG sampai Perguruan Tinggi, terjalin komunikasi dengan baik termasuk dengan masyarakat sekitar dan komunitas seniman se Indonesia.

Manajemen SAU tidak menjelaskan berapa besar nilai keuntungan yang diperolehnya tiap bulan, melainkan menunjukkan bahwa eksistensi lebih dari 40 tahun dan menunjukan ada peningkatan fasilitas, itu dapat diartikan ada keuntungan. Kisaran keuntungan naik turunnya rata-rata ada di kisaran $5 \%$ sampai $10 \%$.

Target market atau pengunjung yang datang ke SAU, seluruh wilayah Indonesia, dari Sabang sampai Merauke, diharapkan dapat mengenal Angklung Udjo dengan datang langsung, mulai dari anak-anak 
sampai dewasa, instansi pemerintah

maupun swasta, lembaga pendidikan dari tingkat PG sampai PT. Untuk luar negeri, seluruh negara menjadi target untuk datang ke Indonesia, dan berkunjung ke SAU, sebagai salah satu pilihan destinasi kunjungan wisata.

Kunjungan yang selama ini datang ke Saung Angklung Udjo Bandung dari seluruh wilayah Indonesia, terutama atas nama wakil pemerintah dari tiap daerah,
Propinsi dan Kabupaten/Kota, karena SAU bekerja sama dengan Dinas Pariwisata dan Kebudayaan, sekarang Kementrian Pariwisata. Dari luar negeri, hampir setiap bulan, wisatawan mancanegara ada yang berkunjung ke SAU, terutama setelah UNESCO di tahun 2010 menjadikan Angklung sebagai warisan budaya asli Indonesia. Gambaran kinerja Saung Angklung Udjo dapat dilihat pada tabel 3 di bawah ini:

Tabel 3.

Perkembangan Usaha Saung Angklung Udjo

\begin{tabular}{|c|c|l|l|l|l|l|}
\hline \multirow{2}{*}{ No } & Variabel Kinerja Bisnis & \multicolumn{3}{|c|}{ Lima Tahun } \\
\cline { 3 - 7 } & & 2010 & 2011 & 2012 & 2013 & 2014 \\
\hline $1 . \mathrm{a}$ & Target Sales/Omzet \%/ (Rp) & 60 & 65 & 70 & 70 & 75 \\
\hline $1 . \mathrm{b}$ & Realisasi Sales/Omzet \%/(Rp) & 65 & 70 & 75 & 75 & 80 \\
\hline $2 . \mathrm{a}$ & Target Keuntungan\%/(Rp) & 5 & 5 & 5 & 5 & 5 \\
\hline $2 . \mathrm{b}$. & Realisasi Keuntungan\%/(Rp) & 5 & 5 & 5 & 5 & 5 \\
\hline $3 \mathrm{a}$ & Target Market Share (\%) & 5 & 5 & 7,5 & 10 & 15 \\
\hline $3 \mathrm{~b}$ & Realisasi Market Share(\%) & 5 & 7,5 & 7,5 & 10 & 15 \\
\hline
\end{tabular}

Sumber : Mutiara Deciana Udjo, 2014 
V. KESIMPULAN DAN SARAN

\section{Kesimpulan}

Saung Angklung Udjo adalah lembaga yang bergerak dalam ekonomi kreatif yang mencakup, produk kreatif berupa angklung yang terbuat dari bahan baku bambu. Keunikan sumber daya Saung Angklung Udjo ditentukan oleh aset berwujud, aset tidak berwujud dan kapabilitas organisasi yang dimilikinya. Angklung adalah aset seni dan budaya, unik dari sisi bahan baku, juga unik dalam memainkannya. Keunikan lain dari angklung adalah dari kemampuan menyesuaikan dan mengimbangi bunyi dan nada dari alat musik modern.

Keunggulan bersaing Saung Angklung Udjo yang dilihat dari strategi market commitment model, sebagian besar telah dijalankan oleh manajemen Saung Anglung Udjo, dan hasilnya dapat dijadikan bahan untuk pengembangan bisnis Saung Angklung Udjo ke depannya.

\section{Saran}

Penelitian tentang keunikan sumber daya dan strategi keunggulan bersaing dengan market commitment model masih sangat terbatas, untuk itu penelitian lanjutan diperlukan. Umumnya penelitian dengan MCM dilakukan untuk dunia perbankan dan untuk perusahaan-perusahaan besar, namun dapat pula dilakukan pada perusahaan mikro, kecil dan menengah, dengan berbagai jenis usaha, termasuk usaha berbasis kreatifitas (ekonomi kreatif). 


\section{DAFTAR PUSTAKA}

Affuah, A. 2004. Business Models: AStrategic Management Approach. NewYork: McGraw Hill

Alfin Samir dan Dwi Larso. 2011. Identifikasi Faktor-faktor yang Mempengaruhi Kinerja UKM Catering di Kota Bandung.Jurnal Manajemen Teknologi. SBM- ITB. Vol. 10 No. 2, 2011.Hal. 163 - 185.

Barney,J, Hesterly W.2010. Strategic Managementand Competitive Advantage, Consepts and Cases.Third Edition.:Pearson.

Creswell.,JhonW.(2009). Research Design: Qualitative, Quantitative, and Mixed Methods Approaches (3rd Edition). Sage Publications.

Covin,J.G\&Covin T.J.1990. Competitive Agresiveness. Environmental Context, and Small Firm Performance. Entrepreneurship Theory and Practice.Spring, 77-89.

Daniel H. Pink, 2005. A Whole New Mind, New York, Riverhead Books.

Dias Satria dan Ayu Prameswari. 2011. Strategi Pengembangan Industri Kreatif untuk Meningkatkan Daya Saing Pelaku Ekonomi Lokal. Jurnal Aplikasi Manajemen, Volume 9, Nomor 1.ISSN 1693-5241.Hal.301-308.

David, Fred R. (2004). Manajemen Strategis. PT. Indeks kelompok Gramedia, Jakarta..

Edy Suandi Hamid dan Y. Sri Susilo, 2011. Strategi Pengembangan Usaha Mikro Kecil dan Menengah di Provinsi Daerah Istimewa Yogyakarta. Jurnal Ekonomi Pembangunan. Vol. 12 Nomo2 1, Juni 2011, hal 45-55.

Gerbono, Anton, Djarijah, A.S., 2009. Aneka Kerajinan Bambu. Yogyakarta. Penerbit Kanisius.

Hitt, Michael A., R. Duane Ireland, and Robert E. Hoskisson, 1999. Strategic Management. Competitiveness and Globalization. England: West Publishing Company.

Ireland,R. Duane, Robert E.Hoskisson, \& Michael A.Hitt. 2009. The Management of Strategy: Concepts and Cases ( $8^{\text {th }}$ Edition). Ohama: South-Western Cengage Learning

Porter, Michael E.1987, From Competitive Advantage to Corporate Strategy.

Harvard Business Review. 1993. Keunggulan Bersaing : Menciptakan dan Mempertahankan Kinerja Unggul. Alih Bahasa Agus Dharma, dkk. Jakarta. Penerbit Erlanga

Putra, Nusa. 2013. Metode Penelitian Kualitatif Manajemen. Jakarta. Raja Grafindo Persada.

Rukmi, Hendang Setyo, Listi Fitria, Fajri Zonda. 2010. Studi tentang Kondisi Industri Kreatif Permainan Interaktif di Kota Bandung Berdasarkan Faktor- factor yang Dipersepsikan Penting oleh Produsen dan konsumennya. Jurnal Rekayasa Itenas. No. 4 Vol. XIV.Januari- Maret 2010. Hal. 1 - 10.

Suryana, 2013. Ekonomi Kreatif, Ekonomi Baru: Mengubah Ide dan Menciptakan Peluang. Jakarta. Penerbit Salemba Empat.

Tambunan, Tulus TH, 2006. Development of Small \& Medium Enterprises in Indonesia from the Asia Pacific Perspective. Jakarta: LPFE- Usakti.

Triaji, "Peranan Non Financial Performance dalam Menentukan Efektifitas Strategi Menggunakan Market Commitment Model di Perbangkan Indonesia (Tanpa Tahun: 3)

Wheelen,Thomas L.,\& Hunger,J.David.2012. Strategic Management and business policy: Concepts.13th ed. Pearson Prientice Hall

Silver, (1997: 60 ) "Strategy in Crisis" dalam Triaji, "Market Commitment Model: Alternatif Strategi Bagi Perbankan di Indonesia" (Tanpa tahun: 10)

http://Inet.detic.com/2013/Produk KerajinanBambu, download, 10 Agustus 2014

http:/teknologi.vivanews.com/ProdukKreatifBambu, download, 10 Aguatus 2012

http:/nunu.web.id/ProdukKerajinanBambu, download 10 Agustus 2014

http/kolomlyrics.blogspot.com/2011/ ProdukKerajinanbambu, download 11 Agustus 2014

hhttp://Okezone. Com/Athurtian/2014/ EkonomiKreatif/ download 21 Oktober 2014.

http://macammakati.blogspot.com/2011/ProdukKerajinanBambu, download 11 Agustus 2014

http://www.itb.ac.id/20/03/2012/ProdukKreatifBambu, download 12 Agustus 2014

https://alviburhani.wordpress.com/2015/01/02/market-commitment-model/download

http://www.greendiary.com/23 October 2009/ download 15 September 2014

http://bamboosaindonesia.multiply.com/12 Agustus 2010/ download 15 September 20154

http://www.opensubscriber.com/19 September 2006/ download 15 September 2014

http://webcache.googleusercontent.com/download 15 September 2014

http://repository.usu.ac.id/download 15 September 2014

http://www.indonesia.travel/en/destination/point-of-interest/saung-mang-udjo

http://wit.co.id/saung-udjo/

https://www.instagram.com/angklungudjo/

Harian Pikiran Rakyat, (12/05/2009, 03/06/2013, 11/07/2014, 10/12/2014, 9/5/2015)

Harian Kompas, ( 1/9/2014, 14/10/2014) 